\title{
Frey's Syndrome After Condylar Fracture: Case Report
}

\author{
Cassio Edvard SVERZUT \\ Alexandre Elias TRIVELLATO \\ Elis Cristina Souza SERRA \\ Emanuela Prado FERRAZ \\ Alexander Tadeu SVERZUT \\ Department of Oral Maxillofacial Surgery and Periodontology, \\ Faculty of Dentistry of Ribeirão Preto, University of São Paulo, Ribeirão Preto, SP, Brazil
}

\begin{abstract}
Frey's syndrome is the occurrence of hyperesthesia, flushing and warmth or sweating over the distribution of the auriculotemporal nerve and/or greater auricular nerve while eating foods that produce a strong salivary stimulus. Frey's syndrome is also known as auriculotemporal syndrome and gustatory sweating. We present a case of Frey's syndrome after a condylar fracture and its treatment by internal rigid fixation. A review of the literature is provided along with mention of a simple test (Minor's test) that can help in the diagnosis of this syndrome.
\end{abstract}

Key Words: Frey's syndrome, condylar fracture, internal rigid fixation.

\section{INTRODUCTION}

The signs and symptoms of Frey's syndrome were first described in 1757 (1), and in 1853 and 1897, the same clinical symptoms were reported after parotid gland infections (1) and with lymphatic nodule abscesses (2), respectively. However, it was only in 1923 that a Frenchwoman named Lucie Frey described this syndrome as occurring after direct damage to the auriculotemporal nerve (3). This syndrome is characterized by the occurrence of hyperesthesia, flushing and warmth or sweating over the distribution of the auriculotemporal nerve and/or greater auricular nerve while eating foods that produce a strong salivary stimulus.

\section{CASE REPORT}

A 23-year-old Afro-American man was referred to the Department of Oral Maxillofacial Surgery and Periodontology (FORP, USP) by his dental practitioner. He complained of acute pain of the mandibular condyle on the left side and the contra-lateral body while eating, with limited opening of the mouth and altered bite. He had a sport accident one week before the symptoms started. There was no other relevant medical or social history.

Examination revealed tenderness of the left mandibular condyle and contra-lateral body with mandibular opening restricted to $30 \mathrm{~mm}$ and deviation to the left side. Intra-oral examination showed an anterior open bite, deviation of $4 \mathrm{~mm}$ of the anterior midline to the left side, diastema and gingival laceration between the mandibular 2nd premolar and the 1st molar. Mandibular manipulation showed bleeding and purulent secretion in this area.

An orthopantomogram showed a well-defined line of fracture of the right body of the mandible, and on the left side a bone discontinuity on the posterior subcondylar area. The modified AP-Towne view was used to assess the medial-lateral displacement of the condyle.

The patient was treated immediately in the out-

Correspondence: Dr. Cassio Edvard Sverzut, Departamento de Cirurgia e Traumatologia Buco-Maxilo-Facial e Periodontia, Faculdade de Odontologia de Ribeirão Preto, Universidade de São Paulo, Av. do Café s/n, Campus Universitário, 14040-904 Ribeirão Preto, SP, Brasil. Tel: +5516-602-4083. Fax: +55-16-633-0999. e-mail: cesve@forp.usp.br 
patient clinic under local anesthesia. Intermaxillary fixation with Erich bars was performed after intensive curettage of the area between tooth 45 and 46 with an intra-oral approach. Oral medication was given (500 $\mathrm{mg}$ amoxicillin every $6 \mathrm{~h}$ and $75 \mathrm{mg}$ potassium diclofenac every $6 \mathrm{~h}$ ). Four days later, under general anesthesia via nasotracheal intubation, the patient was submitted to an open reduction and internal rigid fixation using a 2.0 miniplate system in both areas. In the body fracture two miniplates were used via an intraoral approach; however, in the condylar fracture only one miniplate with bicortical screws was used via a retromandibular approach (Figures 1 and 2). The Erich bars were left to help in the use of elastic bands for midline correction and a suction drain was used for 3 days in the retromandibular approach mainly to avoid hematoma formation.

There was no substantial complaint during the immediate post-operative period. After one month, the midline deviation decreased and the radiographic view of the fractures suggested bone repair, thus the Erich bars were removed and physiotherapy exercises that were implemented right after surgery were continued for two months. However, by the seventh month the patient complained that when beginning to eat, he felt a sharp pain, intense warmth and sweating in the preauricular area on the left side. After one month, the patient's complaints continued, and the Minor's test was performed to confirm Frey's syndrome.

Minor described a very simple test in 1927 (4), which was carried out as follows. The first step consisted of putting an iodine solution on the skin around the pre-auricular area (aqueous antiseptic solution con-

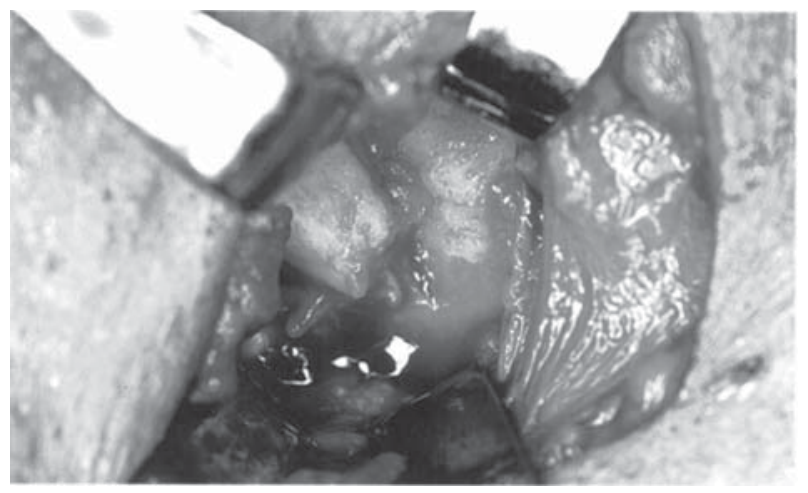

Figure 1. Condylar fracture site exposed after retromandibular approach. taining $10 \%$ polyvinyl-pyrrolidone). The solution was applied evenly on the skin and allowed to dry. Afterwards, the area was covered by a powder layer with a starch base (e.g. flour, cornstarch). The next step was to provide a stimulus by placing lemon drops on the patient's tongue. After a few minutes, the patient complained of sharp pain and heat sensation, and areas of purple coloration could be observed (Figure 3). These areas represented the combination of the secretion of the sweat gland diluted with iodine, which reacted with the starch producing this coloration. Although these areas were small, the diagnosis of Frey's syndrome was confirmed.

The patient was informed and instructed about Frey's syndrome and treatment possibilities. He opted for periodic follow-up reevaluation.

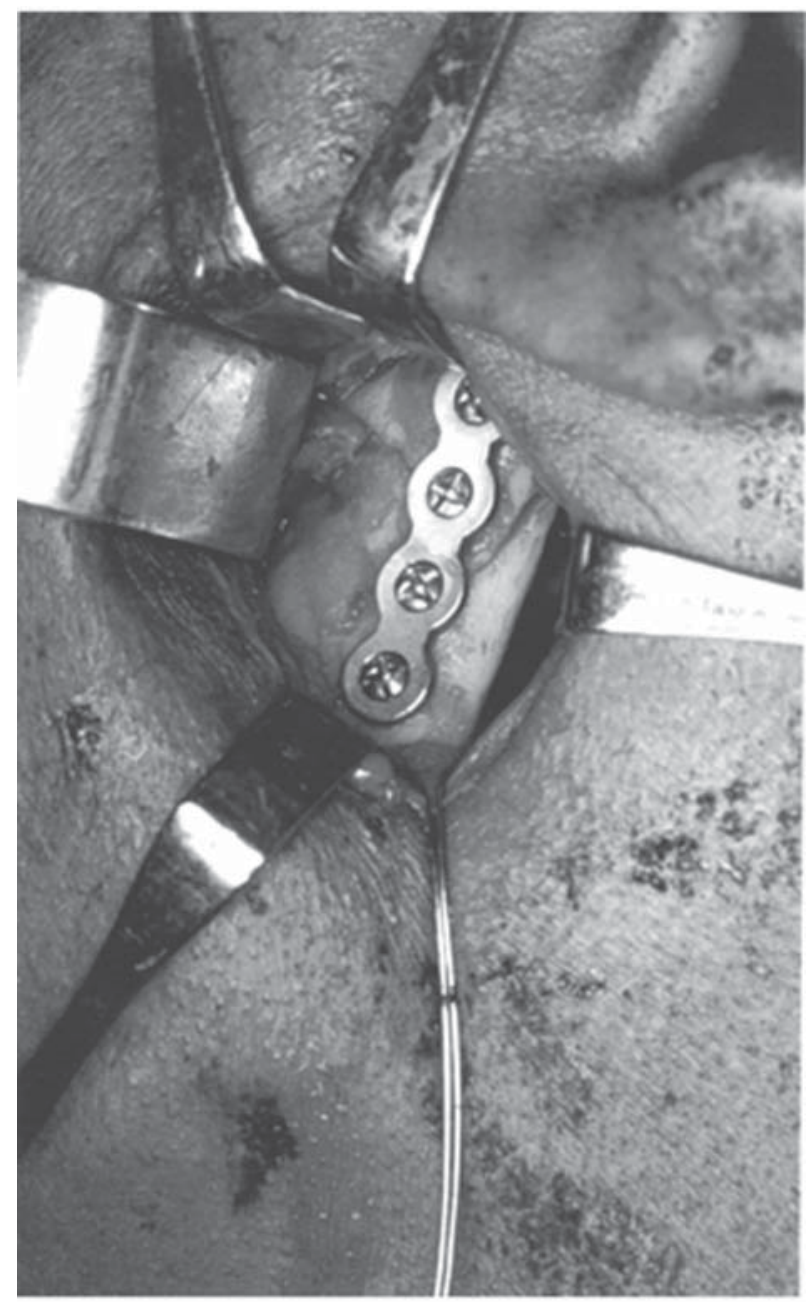

Figure 2. Reduction and fixation of the condylar fracture by one 4-holes 2.0 miniplate and bicortical screws. 


\section{DISCUSSION}

The specific mechanism involved in Frey's syndrome is yet unknown. Through the years, several theories have been proposed. Lucie Frey (3) suggested that the damaged auriculotemporal nerve is invaded and irritated by healing tissue. Freedberg (5) believed that the damage to the nerve may cause destruction of sympathetic fibers leading to parasympathetic hypersensitivity and stimulation. The more acceptable theory is called the Theory of Aberrant Regeneration, which is based on defective nervous regeneration. The misdirection of regenerating parasympathetic fibers to denervated sweat glands results in the simultaneous activation of parotid and sweat glands $(6,7)$.

The auriculotemporal nerve is the terminal of the mandibular branch of the trigeminal nerve. It is a mixed nerve and has sympathetic and parasympathetic fibers. The sympathetic fibers are responsible for the inhibition of salivary stimulation and vasoconstriction of the vessels present in the parotid gland, temporomandibular joint and skin over the auriculotemporal area and external acoustic meatus. The parasympathetic fibers are carried to the parotid gland and are responsible for the stimulation of salivary secretion and vasodilation. The greater auricular nerve is responsible for the sensitivity of the skin on the submandibular, pre-auricular and cervical areas. Some fibers have direct contact with the auriculotemporal nerve.

About 30 to $50 \%$ of the patients who undergo total or partial parotidectomy report having the typical symptoms of Frey's syndrome (8), and in approximately $15 \%$ rate their symptoms as severe $(1,9)$. An important preventive procedure during a parotid exci-

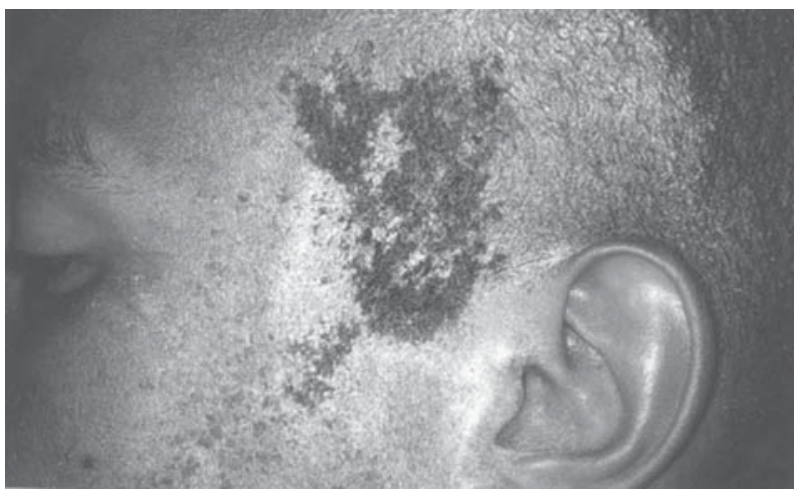

Figure 3. The Minor's test showed areas where the secretion of sweat gland diluted with iodine, which reacted with the starch. sion is the interposition of the fascia lata, sternocleidomastoid and platysma muscles $(8,10)$. These symptoms have also been documented following surgeries of the cervical lymph nodes and submandibular gland (11), surgical approach to the temporomandibular joint (12), orthognatic surgery (13), condylar trauma (14-16), and also in some normal individuals while eating sour or spicy food (17).

The relation between fracture displacement of the condyle and Frey's syndrome adds further support to the view of the intimate anatomical relationship of the auriculotemporal nerve with the capsule of the temporomandibular joint (15). However, despite the proximity of these structures and the high incidence of condylar fracture $(25 \%$ to $36 \%$ of mandibular fractures), Frey's syndrome is rare after this type of fracture $(14,15)$.

The occurrence of Frey's syndrome may be more frequent than reported in the literature (16). Symptoms are sometimes delayed and can be very slight; often neither the patient nor the surgeon realizes their presence. The symptoms usually appear 5 weeks to one year after nerve damage (18). This makes it more difficult to determine the real etiologic factor.

Another important point is the approach used in surgery. Can a retromandibular approach lead to Frey's syndrome? During dissection, some structures are exposed, including the retromandibular vein and branches of facial nerve, specifically the marginal mandibular branch and cervical branch. The latter in this dissection passes through the parotid gland, where the auriculotemporal nerve runs. This approach offers an excellent field to visualize the condyle and putting the internal apparatus in place (19). However, it is theoretically possible that it can lead to Frey's syndrome. Swanson et al. (12) studied two types of preauricular approaches to the temporomandibular joint. They found that minor incisions and less parotid manipulation are associated with lower indices of Frey's syndrome.

An ideal treatment would be one that could produce permanent suppression of the symptoms, while offering a good success rate, minimal invasiveness and few side effects (8). The literature reveals three options for treatment: surgical measures, chemotherapy and radiation therapy. The intensity of symptoms is very important in choosing the correct treatment. Radical surgeries, such as an intracranial resection of the glossopharyngeal nerve and a Jacobson anastomosis are pro- 
posed in critical cases (8). This method is effective but extremely drastic in view of the degree of disability (13). Drug treatment strategies involve the topical and systemic administration of anticholinergics. However, topical application can lead to skin irritation and systemic administration at the required doses could cause side effects (accommodation difficulty, onset of glaucoma, tachycardia) (20). In addition to causing skin irritation, topical treatment with anti-hyperhidrotics has also proved to be problematic and unpleasant for patients because of its ineffectiveness despite frequent application (8). Von Lindern et al. (8) reported that treatment with type A botulinum toxin represents a promising therapeutic approach. It has been used successfully for years as a local muscle relaxant in the field of focal dystonia. Long-term experience has also been gathered in the treatment of blepharospasm, spasmodic torticollis, and hemifacial spasm (21). The range of applications of botulinum toxin is steadily increasing because of its efficacy and ease of administration (8).

It should be emphasized that all treatments must be guided by the patient's complaints. The patient's social life can be greatly restricted because of localized symptoms and pain. In this case, proper therapy should be provided, surgical or otherwise. However, in some cases, symptoms can be minor and well tolerated by the patient, and thus, drastic treatment should be avoided. Finally, there have been reports in the literature noting improvements of symptoms over time in patients who received no treatment (16).

\section{RESUMO}

A Síndrome de Frey é compreendida como a ocorrência de hiperestesia, aumento de temperatura e suor na região da distribuição do nervo auriculotemporal e/ou nervo auricular maior, desencadeado pelo simples ato de se alimentar quando existe um grande estímulo salivatório. É também conhecida como Síndrome Auriculotemporal e Suor Gustatório. Esse artigo identifica um caso de Síndrome de Frey após fratura de côndilo mandibular que foi tratada com fixação interna rígida. Adicionalmente esta revisão da literatura detalha um teste simples (teste de Minor) que pode auxiliar no diagnostico desta síndrome.

\section{REFERENCES}

1. Baillarge JGF. Mémoire sur l'oblitération du canal de Stenon. Gaz Med 1853;23:194.

2. Weber F. A case of localized sweating and blushing on eating, possibly due to temporary compression of vasomotor fibres. Trans Clin Soc 1897-8;31:277-280.
3. Frey L. Le syndrome du nerf auriculo-temporal. Rev Neurol 1923;2:97-104.

5. Minor V. Ein neues verfahren zu der klinischen untersuchung der schweissabsonderung. Dtsch Z Nervenheilkd. 1927;101;302.

5. Freedberg AS, Shaw RS, McManus MJ. The auriculotemporal syndrome - A clinical and pharmacologic study. J Clin Invest 1948;27;669-676.

6. Glaister DH, Hearnshaw JR, Heffron PF, Peck AW. The mechanism of post-parotidectomy gustatory sweating (the auriculotemporal syndrome). Br Med J 1958;2:942-946.

7. Gardner WJ, McCubbin JW. Auriculotemporal syndrome: gustatory sweating due to misdirection of regenerated nerve fibres. J Am Med Assoc 1956;160:272-277.

8. Von Lindern JJ, Niederhagen B, Bergé S, Reich RH. Treatment of Frey's syndrome with type A botulinum toxin: Case report. J Oral Maxillofac Surg 2000;58:1411-1414.

9. May JS, McGuirt WF. Frey's syndrome: Treatment with topical glycopyrrolate. Head Neck 1989;11:85-89.

10. Sood S, Bradley PJ. Parotid surgery and Frey syndrome. Arch Otolaringol Head Neck Surg 2000;126:1168.

11. Gordon AB, Fiddian RV. Frey's syndrome after parotid surgery. Am J Surg 1976;132:54-58.

12. Swanson KS, Laskin DM, Campbell RL. Auriculotemporal syndrome following the preauricular approach to the temporomandibular joint surgery. J Oral Maxillofac Surg 1991;49:680-682.

13. Tuinzing DB, Van Der Kwast WAM. Frey's syndrome: a complication after sagittal splitting of the mandibular ramus. Int J Oral Surg 1982;11:197-200.

14. Zöller J, Herrmann A, Maier H. Frey's syndrome secondary to a subcondylar fracture. Otolaryngology 1993;8:751-753.

15. Mellor TK, Shaw RJ. Frey's syndrome following fracture of the mandibular condyle: Case report and literature review. Injury 1996;5:359-360.

16. Martis C, Athanassiades S. Auriculotemporal syndrome (Frey's syndrome), secondary to the fracture of the mandibular condyle. Plast Reconstr Surg 1969;44:602-603.

17. Gorlin RJ, Cohen MM, Levin LS (Editors). Syndromes of the head and neck. New York: Oxford University Press. 1990;615616.

18. Olson RE, Walters CL, Powell WJ. Gustatory sweating caused by blunt trauma. J Oral Surg 1977;35:306-308.

19. Ellis III E, Dean J. Rigid fixation of mandibular condyle fractures. Oral Surg Oral Med Oral Pathol 1993;76:6-15.

20. Büning K, Diekmann J. Aufreten und therapie des Frey-syndroms nach parotidektomie. Münch Med Wochenschr 1978;27:120.

21. Brin MF. Interventional neurology: Treatment of neurological conditions with local injection of botulinum toxin. Arch de Neurobiol 1991;54:7. 